Japanese Yearbook on Business History - 1997 / 14

\title{
The Rise of Salaried Managers
}

Comparing Japan and South Korea

\author{
Tamio HATTORI \\ Dōshisha University
}

W HAT SORT OF change takes place among the people who run an enterprise, beginning with the time of its establishment and then as it grows and accumulates years? This is a question of great interest from a business history point of view. In most cases an enterprise is established by an individual, a family, or a small group of people, and eventually the ones who were doing the lion's share of management grow old, retire, and someone else takes their place. Can some pattern be found in who that someone else is, or in what circumstances that someone else takes over? And if there should be some pattern, is it somehow influenced by traditional values in the society in which that management exists?

In this paper I propose to consider these questions through a comparison of Japan and South Korea. Pivotal to this comparison will be three questions: In present-day Japanese and South Korean enterprises to what extent do functional capitalists take part in decision-making in the role of top-level management? As the obverse to this, to what extent do salaried managers who own almost no shares make decisions in the role of top management? Are there any differences between Japan and South Korea in this 
matter, and, if there are, what kind of factors are influencing such differences? I propose to investigate the matter empirically and see if we can obtain any meaningful indications.

ON COMPARISON AS A METHOD

Before embarking on the main task, I would like to draw attention to a few problems connected with making the proposed comparison.

The fact that ought to be pointed out first is that the Japanese and South Korean enterprises that I shall attempt to compare have considerably different economic histories. In the case of Japan, industrialization began from the latter half of the nineteenth century, by the end of the war in 1945 huge zaibatsu like Mitsui, Mitsubishi, Sumitomo, and Yasuda had been formed, and after the war these giants were dissolved. With the dissolution, enterprises affiliated with zaibatsu were cut off from their parent zaibatsu, zaibatsu families and zaibatsu head offices were excluded from owning shares in the enterprises, and zaibatsu families, head offices, and the top managers of affiliated enterprises were forcibly excluded from managing any of the enterprises. The result was that, in the once zaibatsu-related enterprises that have been representative of postwar Japan, (managerial) control by means of salaried managers was accomplished at a single stroke. ${ }^{1}$ But in those enterprises that were not forced to dissolve there were, naturally, cases in which functional capitalists continued to exist, and, as I shall discuss in this paper, in many of the enterprises established after the war there also continued to exist functional capitalists. $^{2}$

Korea, on the other hand, was merged with Japan at the beginning of the twentieth century, and during that time the establish-

\footnotetext{
${ }^{1}$ In this paper I use the term "salaried manager" in the same sense as that given to it by Hidemasa Morikawa: "a manager who has no ownership function but who specializes in the managerial function" (Morikawa 1996, 7).

${ }^{2}$ By "functional capitalist" I mean a capitalist who holds both an ownership function and a managerial function. If we follow the definition of Morikawa, it refers to the manager of a founder enterprise as well as of a family enterprise.
} 
ment of a modern enterprise by Koreans was very severely restricted. There are very few enterprises still in existence today that were founded during that time. The overwhelming majority of contemporary enterprises were established after the liberation from Japan, or more specifically from the latter half of the 1960s, when industrialization began in earnest. As a result, today, some thirty to forty years after their establishment, many of the enterprises have reached a time of generational change. Also, in the process of industrialization chaebol (South Korea's zaibatsu) have been formed, as represented by such giants as Samsung and Hyundai. This was partly due to South Korea's industrialization being extremely rapid and powerfully propelled forward under great restrictions in such aspects as resource distribution or the supply of talented personnel (Hattori and Satō 1996, ch. 11). How much the growth of the chaebol pulled along South Korea's economic growth can be inferred from the fact that the proportion of business activity occupied by these chaebol in the South Korean economy kept on increasing up to the mid-1980s. ${ }^{3}$

The historical backgrounds in which South Korea's and Japan's enterprises have existed are, as I said above, different. Another difference between Japan and South Korea is the concept of the group known as "the family." For reasons of space I shall not enter into the matter further in this paper, but suffice it to say that, whereas in Japan, where continuation of the institutional aspect of "the family" was viewed as important, so that the most suitable person to carry on the institution was chosen as successor regardless of the blood relation, in South Korea continuation of the blood relation aspect of "the family" was viewed as important, so that being a blood relative was considered a necessary condition for the successor (Hattori 1988, chs. 1 and 3). I believe that this concept of "the family," and in particular the difference in attitude towards successors, is another point that has given a different coloration to

${ }^{3}$ While it is difficult to calculate precisely how much of Korea's overall economy was controlled by its chaebol, we do know that in the first half of the 1970 s the top five chaebol held approximately 3.5 percent of the country's GNP, and that this percentage increased thereafter till it reached the 10 percent level in the first half of the 1980s. In the second half of the 1980s this figure fell somewhat, rising again as the mid1990s were approached, till in 1995 it seems to have reached the 9.5 percent level again. For more on this, see Hattori 1994b. 
enterprises in Japan and South Korea.

With these ideas in mind, in this paper I have taken for my comparison of Japanese and South Korean enterprises approximately 350 listed Japanese enterprises capitalized at 10 billion yen or more and founded after the war, along with approximately 450 listed South Korean enterprises capitalized at 10 billion won or more, then I have compared and analyzed the relationship between managers and shareholders in these enterprise groupings. In the case of Japan these figures represent no more than about one-sixth of the listed enterprises, but in the case of South Korea the figure corresponds to two-thirds of listed enterprises, which makes a difference in representativeness. Still, I gave priority to matching, in Japan and South Korea, the time elapsed from the founding of the enterprises. This is because it is thought that the special features of family configurations will become obvious as to any succession in those enterprises (Hattori 1976 and 1988). In addition to this, in the case of Japan the peak in enterprise establishment occurred from the end of the 1940s through to the first half of the 1950s, but in South Korea the peak took place some 15 to 20 years later. While this time difference may affect my analysis, still, because one generation is generally considered to be thirty years, I would like to think that any effect it has will still be within the permissible range.

\section{CHANGES IN MANAGEMENT FORMS}

\section{THE ARGUMENT OF BERLE AND MEANS}

As an enterprise in the course of its history expands its scale of operations, there is a tendency for the influence of the family or individual who founded that enterprise gradually to weaken, for share ownership to become diluted, and for management of the enterprise to be taken over by salaried managers. This idea was first proved by Berle and Means. That this sort of tendency can also be found in South Korean enterprises has already been proved by this writer as well. If I may sum it up here, in an analysis of approximately 320 listed South Korean enterprises as of 1982, it was found that, the larger the scale of capital, the more the percentage of share ownership in the name of a family decreased and the propor- 
tion of families occupying managerial posts of director/trustee or higher also decreased. However, it simultaneously became clear that the larger the scale of the enterprise, the more increase there was in "reciprocal holding" of shares among affiliated enterprises, and the shareholdings in fact controlled by families were quite large (Hattori 1984).

The study mentioned above was an analysis between scales at one given point in time, but a similar situation was found to be true in a comparison at two given points in time. In a comparison between 1982 and 1992, during which the scale of capital increased by from six to ten times, it was again found that the share ownership of families dropped and their percentage of participation in management was declining. It is believed that, as capital increases and the organization expands, the fund-providing limitations of the family naturally bring about such a result (Hattori 1994a, b).

\section{HIDEMASA MORIKAWA'S CRITIQUE AND REVISIONS}

It was Hidemasa Morikawa who, while fundamentally agreeing with the argument of Berle and Means that enterprises change their forms of management as they grow, added a counterargument in regard to the logic concerning why such changes occur (Morikawa 1996). Morikawa argued that there is an unchanging tendency in management forms for "founder enterprises" to change into "family enterprises" and then in turn to become "manager enterprises." He theorized that, for a "founder enterprise" to change its form into a "family enterprise" inherited by the founder's family is a natural move, given the biological limitations of human beings, and that to go on and change into a "manager enterprise," regardless, is caused by the fact that "family managers" cannot effectively form the network that efficiently manipulates the various strata within the organization, and that, even in terms of abilities, there is a higher possibility of procuring able, talented personnel from a wider possible pool than can be found in a single family.

To back up his theory, Morikawa quantitatively analyzed the rise of salaried managers in large Japanese enterprises from the Meiji period on, and he was able to establish that his theory fits the facts (Morikawa 1996, ch. 3). He then went on to claim that the move from "founder enterprise" or "family enterprise" to "manager 
enterprise" would generally occur, purely from the necessities of management, so that as a result such a progression in forms of management would take place as described above in any society, with an analysis of newly industrialized economies in Asia (Morikawa 1996, ch. 2). Implied in this claim is opposition to the position of Shigeaki Yasuoka that "unless one clarifies the 'social climate' that supports the institutions situated outside the formal institutions that are thought to be based on racial traits, the problem of the authority of the manager will also end up unclarified" (Yasuoka 1995, 9).

Morikawa's position includes not a few things that can be supported. But there is as yet an insufficient accumulation of research findings on changes in the form of enterprise management in societies outside Japan, and especially in Asia, for complete agreement to be given to his position. Thus, for example, where does the phenomenon of "the trend for family managers to become salaried managers" propounded by Akira Suehiro fit within Morikawa's theory (Suehiro 1993)? Or what about the phenomenon of the partitioning of an enterprise in a period of generational change that is discussed in one of my articles (Hattori 1994b)? The empirical analysis I make in the pages that follow is an attempt to consider, by analyzing the case of South Korea, whether Morikawa's position holds or not even in a newly emerging industrial country, and to provide material for a judgment.

THE ADVANCE OF SALARIED MANAGERS: JAPAN AND SOUTH KOREA COMPARED

\section{EXTRACTING OF SAMPLES}

To achieve the purpose stated above, I used the following modus operandi to extract samples. In order to provide data on Japan, I chose, from Kaisha shiki hō [Company quarterly report] (4th series, 1995), enterprises established after the Second World War whose capital as of 1995 was over 10 billion yen. For South Korea I used Volume 1 (Listed enterprises) of the 1995 edition of Kaisha nenkan [Company yearbook] published annually by the Meil Kyongjae Shinmunsa (Meil Economic News Agency), to select enterprises with a capital of 10 billion won or more. Among the South Korean 
Figure 1. Scale of Capital of Enterprises Surveyed

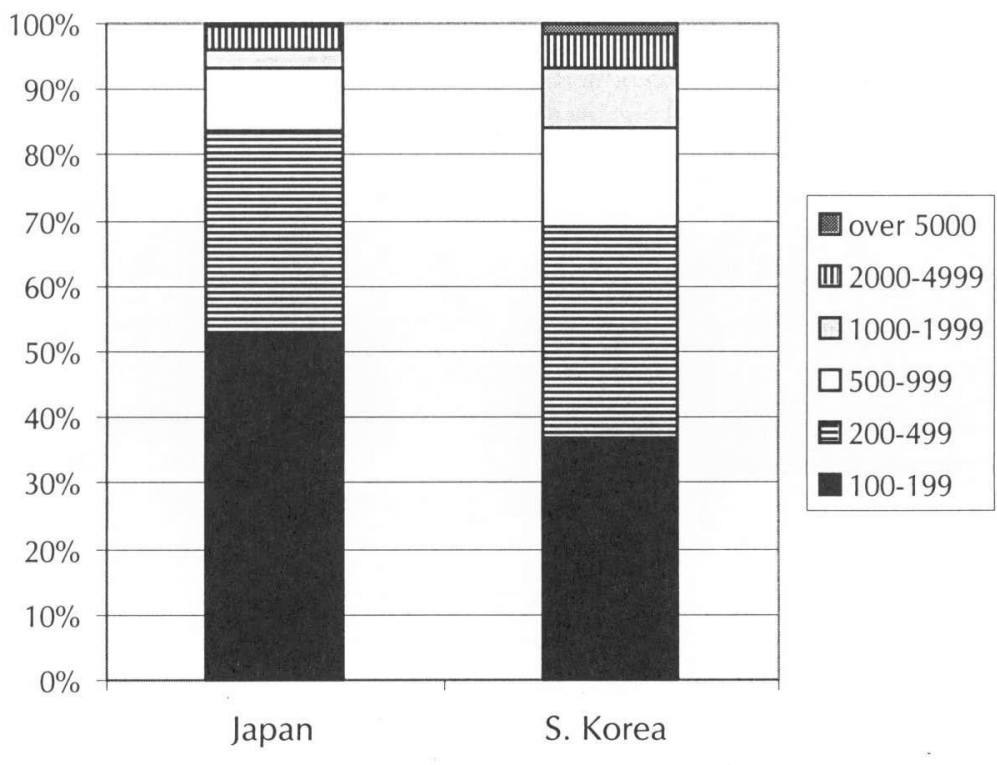

Table 1. Scale of Enterprises Surveyed

\begin{tabular}{l|c|c}
\hline & JAPAN & S. KOREA \\
\hline $100-199$ & 186 & 168 \\
\hline $200-499$ & 112 & 148 \\
\hline $500-999$ & 34 & 69 \\
\hline $1000-1999$ & 10 & 41 \\
\hline $2000-4999$ & 12 & 23 \\
\hline Over 5000 & 2 & 8 \\
\hline TOTALS & 356 & 457 \\
\hline
\end{tabular}


enterprises are included a few that were established before Korea's liberation, but these are very few in number (about 20). As stated earlier, the Japanese enterprises that fit the given conditions amount to less than one-sixth of all Japan's listed enterprises, whereas the South Korean enterprises correspond to approximately two-thirds of South Korea's listed enterprises. In a sense, then, the reliability of my analysis will be higher in regard to South Korea.

Figure 1 and Table 1 on the preceding page show the number of enterprises analyzed in this study (grouped by scale of capital) and the percentage each group occupies in the total number of samples. The unit value for the figures in the groupings by scale of capital is one hundred million yen for Japan and one hundred million won for South Korea. Since the exchange rate of yen to won is a little over 1:7, in the case of South Korea there are relatively smallscale firms included in the sample as compared with the Japanese enterprises sampled, and as a result the possibility is higher that a large number of "nonmanager enterprises" are included. The number of enterprises that fitted the conditions described earlier came to 356 for Japan and 457 for South Korea. From the table (Table 1) of scale distribution, it can be seen that in both Japan and South Korea the smallest-scale enterprises (under twenty billion yen/won) were the most numerous portion, and the trend for higher levels increasingly to decrease in number is rather abrupt in Japan, more gradual in South Korea. As a result, in Japan enterprises with less than fifty billion yen of capital add up to more than ninety percent of the total, whereas in South Korea enterprises with less than fifty billion won of capital come to about eighty percent of their total. Thus South Korea has relatively more large-scale enterprises. The largest of the enterprises included in the "Over 500 billion yen/won" category are NTT in Japan, with 720 billion yen, and Daewoo Heavy Industries in South Korea, with one trillion, eight hundred billion won. This latter's capital is far and away the largest in South Korea; the enterprise in second place is Commercial Bank of South Korea, with 850 billion won (see also Figure 3-2 on page 23). 
Besides the sources mentioned earlier I also used the Yakuin shiki $h \bar{o}$ [Company officials quarterly report] (1996 edition) to find out who in each enterprise held the authority to represent that enterprise and to see if the largest shareholder(s) and the official(s) authorized to represent the enterprise were one and the same person(s) or not.

The sample for Japan totaled 356 enterprises. Naturally, this sampling included cases of former zaibatsu-related enterprises that made new starts, such as Mitsui Bussan, Mitsubishi Shōji, Sumitomo Metals, etc.; it also included former government enterprises like Tokyo Electric Power, and Japan Railways as well. So first I looked at those enterprises that had a high "rate of shareholding by officials." Now, it is difficult to agree on how much of a rate of holding is "high," but I decided to set the criterion at 5\%. My reason for this was that the limit on city banks' holdings of any one company's shares is set at under $5 \%$, and this can be understood as one of the generally accepted criteria for enterprise control. Of the 356 enterprises in our sample, 65 fit into this category. The highest rate of official shareholding reached an astonishing level of $56.9 \%$; in 30 of the enterprises the rate exceeded $10 \%$, and in the great majority of these cases it was either the president (or chairman) himself or a related enterprise that was the largest shareholder. The situation was not much different in the remaining 35 enterprises, except that fewer of the enterprises had an individual registered as the largest shareholder. Yet, if one adds together the shares dispersed among people connected with the families, these still amount to a considerable percentage. Accordingly, in these 65 enterprises it is "functional capitalists" who hold the decisionmaking authority in their grasp. In this paper I shall refer to this sort of enterprise as a "nonmanager enterprise," and to an enterprise in which a salaried manager is appointed to a position in which he can make decisions affecting the whole enterprise, as a "manager enterprise." From this perspective, the proper judgement would be that in these 65 enterprises we cannot yet see the appearance of salaried managers holding decision-making authority.

If we look at these enterprises in terms of their capital, we find that there is only one among the 34 enterprises with capital of 100 
billion yen or more, four among the 34 with capital of 50 billion yen or more, eight among the 44 with capital of 30 billion yen or more, and 52 among the 65 with capital of less than 30 billion yen. It seems safe to say that enterprises where salaried managers have not come to the fore are more numerous among the relatively small-scale enterprises.

Even if it is true that, though the shareholdings of officials are insignificant, top management families without official posts, or else related companies, own shares and these officials exercise substantial control over those shareholders, then this amounts to almost the same thing as ownership by an individual. Hence I calculated the total ownership if one added to officials' shareholding what was owned by family members in top management, related enterprises, foundations, and so on, and the number of "nonmanager enterprises" that exceeded the $5 \%$ criterion came to 106 , leaving 250 "manager enterprises." That is, roughly under one-third of the sample are "nonmanager enterprises." And the average capital of the "nonmanager enterprises" is 24.01 billion yen, with an average share control rate of $21.5 \%$. In contrast, the average capital of the "manager enterprises" is 53.66 billion yen, with an average share control rate of $0.6 \%$. In terms of scale, then, one can see that there is quite a large difference between the "nonmanager enterprises" and the "manager enterprises."

Let us look more closely at the distribution of this control rate. There are 5 enterprises with a control rate exceeding 50\%, 11 altogether exceeding 40\%, 24 altogether exceeding 30\%, and 47 altogether exceeding $20 \%$, so that the majority of enterprises have a control rate under $20 \%$. If we look at these enterprises by the scale of the average capital, those in the over $10 \%$-under $20 \%$ category are the largest, with approximately 26.15 billion yen, followed by those in the over $20 \%$-under $30 \%$ category, with approximately 25.37 billion yen. Those over $30 \%$ and those under $10 \%$ are smaller in scale than these (see Figure 2 and Table 2 on the facing page). We can gather from this a trend showing that, the stronger the power of control becomes, the relatively smaller the scale of capital becomes, but this does not mean that a strong tendency can be read into its distribution. 
Figure 2. Distribution of Managers' Share Control Rates

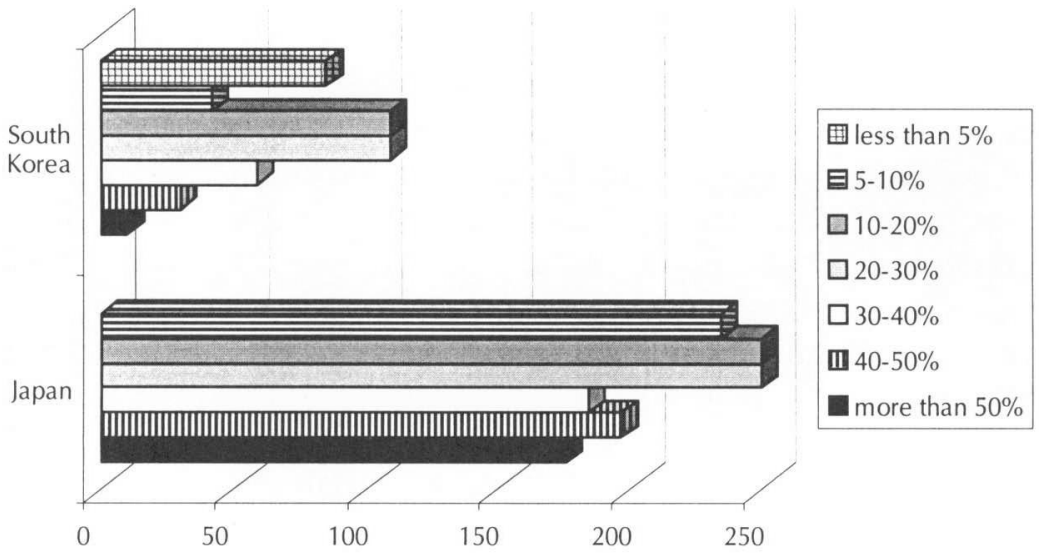

Table 2. Share Control Rate of Specific Managers

\begin{tabular}{l|c|c|c|c}
\hline & JAPAN & $\begin{array}{c}\text { AVERAGE CAPITAL } \\
\text { (BILLION YEN) }\end{array}$ & S. KOREA & $\begin{array}{c}\text { AVERAGE CAPITAL } \\
\text { (BILLION WON) }\end{array}$ \\
\hline Over 50\% & 5 & 17.58 & 10 & 19.86 \\
\hline $40 \%-$ under 50\% & 6 & 19.65 & 30 & $\begin{array}{c}86.82 \\
(26.46)\end{array}$ \\
\hline $30 \%-$ under 40\% & 13 & 18.42 & 59 & 37.54 \\
\hline $20 \%-$ under 30\% & 23 & 25.37 & 109 & 39.3 \\
\hline $10 \%-$ under 20\% & 41 & 26.15 & 109 & 68.59 \\
\hline $5 \%-$ under 10\% & 18 & 23.47 & 42 & 62.06 \\
\hline under 5\% & 250 & & 85 & \\
\hline Totals & 356 & & 444 & \\
\hline
\end{tabular}


From the analysis above it is clear that, in the comparatively new enterprises in Japan's industrial world approximately one-third are what are referred to in this paper as "nonmanager enterprises." In these enterprises, share owners are engaged in management of the enterprises as functional capitalists, and they control on average $21.5 \%$ of the shares. The average year of establishment of these enterprises is 1958. It can be said that the founders have maintained considerable controlling power even though nearly forty years have passed since their establishment. At the same time, however, we could take notice of the fact that more than two-thirds of our sample enterprises have already become "manager enterprises." Let it be noted, however, that there are cases that have been missed in this analysis. They are cases in which the founder or his family fall under the 5\% shareholding criterion established as the arbitrary norm for this study, but whose enterprise is generally recognized as being a family enterprise, or cases in which the successors are chosen from the families. Representative examples of this are Wacoal in the textile field, San'yō in electric machinery, and Alps in electronics, and if you disregard the assumptions of this study, Matsushita in household electrical appliances and the automobile maker Toyota. How can such cases be possible? I shall touch upon this question later.

\section{THE SITUATION IN SOUTH KOREA}

For South Korea our analysis covers 457 enterprises. This sample corresponds to approximately two-thirds of South Korea's 712 listed enterprises. Now, the special feature of South Korea's enterprises is that most of them are enterprises affiliated with enterprise groups. Of the 457 in our sample, 266 , or just under $60 \%$, belong to some enterprise group or other. While some bank-related or government-enterprise-related organizations are included in the groups, most of the enterprise groups are owned by families. Accordingly, whenever a given enterprise is affiliated to a group and its shareholders are enterprises within the group, I counted it as an enterprise whose owner(s) can exercise control rights even in regard to the holdings of the share-owning enterprises. I based this decision on the following grounds. 
In Japan, too, subsidiary enterprises are included among the sample, and the general situation is that the parent companies own a high percentage of shares. In most cases, however, these parent companies are themselves manager enterprises, and though all influence of the parent companies on the subsidiaries cannot be eliminated, the ones who make the decisions in these parent companies are salaried managers. If we look, however, at the management structure in South Korean enterprises, we find that, in group enterprises at least, each affiliated enterprise has the post of president or chairman, but above that post there are other posts called "group chairman" and "group vice chairman," to which posts in many cases members of the family that owns the group are appointed. It is only possible to judge on a case-by-case basis how much authority the "group chairman" might have, and how much authority the president or chairman of the subsidiary shares in; as a result, one cannot say with certainty that the president or chairman of each of the affiliated enterprises holds the ultimate decision-making authority.

There is another point to be made in regard to the relationship between posts and authority. As a general rule, the post of chairman or the post of president is inseparable from a distribution of authority. This is when one person is appointed to these posts. But in South Korea it is not unusual for there to be enterprises with a plurality of presidents. What this means is that the term "president" does not indicate a "post" so much as a type of "qualification" (Matsumoto 1985, 51-52; Hattori 1988, 127). In this case, then, there has to exist an ultimate decision-making authority above the individual presidents. Sometimes this is the group chairman, at other times it is the chairman; to follow the reasoning of Hidemasa Morikawa, if there is not a non-blood-related salaried manager in the post of group chairman or chairman, that enterprise cannot be called a "manager enterprise." To be more specific, if it is a group enterprise then the group chairman, and if it is a non-group enterprise then the chairman (or president) has to be a salaried manager before that enterprise can be called a "manager enterprise." With this reasoning taken as our premises, let us proceed to our analysis. 
First of all, when we look at South Korean enterprises that exceed the $5 \%$ criterion introduced in the analysis of Japanese enterprises, by scale of capital, we find that only one enterprise out of 10 exceeds $5 \%$ in the "Over 500 billion won" grouping, and 14 out of 23 in the "from 200 billion up to but not including 500 billion" grouping fit in this category, of which 11 exceed $10 \%$. Even in the "from 100 billion up to but not including 200 billion" grouping 28 out of 41 enterprises exceed 5\% (25 of them exceeding $10 \%)$. In other words, in South Korea it is extremely common for a certain specific manager to hold large controlling power over shares. Figure 2 and Table 2 show the distribution of share control rates and the average capital of each of the scale levels.

In South Korea, as well as in Japan, as the share control rate becomes higher, the average capital falls. When the latter exceeds $50 \%$, the former is 20 billion won and under, and it gradually increases as share control rates decrease. In the over $40 \%$-under $50 \%$ range it is abnormally large, but this is because of the inclusion of Daewoo Heavy Industries, whose capital is exceptionally large; if Daewoo is excluded the average is 26.46 billion won. Thus, in South Korea as well, as the scale of the enterprise becomes larger the share control rate as a general rule becomes smaller.

The point of greatest difference from Japan is that, whereas in Japan nearly two-thirds of the enterprises in the sample were under $5 \%$, in South Korea 218 enterprises, or approximately one-half of the sample, are concentrated in the over $10 \%$-under $30 \%$ range, with about 100 enterprises above that range and 130 below that range. The total number of enterprises below $5 \%$ came to less than $20 \%$ of the total sample. And even if we raise our criterion to $10 \%$ to take into account the different situations in Japan and South Korea discussed earlier, in $70 \%$ of the enterprises specific managers (including some cases in which there is an overlapping with more than one family) still clear this criterion. Enterprises that are exceptional cases in this whole situation, in that a specific family does not have a controlling power in the area of ownership or that members of that family are not appointed to management posts, are to be found mostly in the financing industry. There are enterprises like Kia and Pohang Iron \& Steel Co. in the manufacturing industry, and Yuhan Corp. in the pharmaceutical industry, but in 
the present state of affairs in South Korea they really have to be considered rare cases.

From the evidence we have seen, it can be said that in South Korea a specific family or a plurality of families still control both aspects-management and ownership- in the overwhelming majority of enterprises. In such a situation, it would be possible to say that the formation of "manager enterprises" in which salaried managers are able to control things right up to the ultimate decision-making is still too early.

\section{COMPARING JAPAN AND SOUTH KOREA}

Figures 3-1 and 3-2 on the following pages look at the relationship between the share control rates of specific individuals or families, and capital. Figure 3-1 plots enterprises in the top $20 \%$ of share control percentage (71 enterprises in Japan, 89 in South Korea), while the latter plots the top $20 \%$ in terms of scale of capital. A dot $(\bullet)$ stands for a Japanese enterprise and triangle $(\boldsymbol{\Delta})$ for a South Korean enterprise. Looking at Figure 3-1 first, we can see quite clearly that the relation between share control rate and capital is one that slopes down to the right in Japan-in other words, if the scale of capital rises, the share control rate goes down. But the relationship is not so clear in South Korea. It cannot be said that there is no trend towards a downward slope to the right, but it is not very clear. It might be worth noting in passing that the share control rate of Japan's 71st enterprise is $12.9 \%$, while that of South Korea's 89 th enterprise is $31.7 \%$. This trend is even clearer in Figure 3-2. Almost all of the enterprises in Japan capitalized on a large scale line up along the $0 \%$ line. There are exceptions, but they are enterprises that rank comparatively low in the top $20 \%$. It can be seen that in South Korea, however, even enterprises that are capitalized on a considerably large scale maintain a considerably high share control percentage. Even if we leave out of the picture the supercolossal enterprise at the far upper right, there are several enterprises whose control rate is in the $20 \%-\$ 40 \%$ range even though the scale of their capitalization is 400 to 500 billion won. Just judging from this figure it is impossible to detect any clear tendency. There are a few x's lined up along the $0 \%$ line at the upper left of the figure; these all represent financial institutions. In passing 
Figure 3-1. Distribution of Share Control Rates and Capital (1)

By capitalization

Japanese top $20 \%$ (71 enterprises)

South Korean top $20 \%$ (89 enterprises)

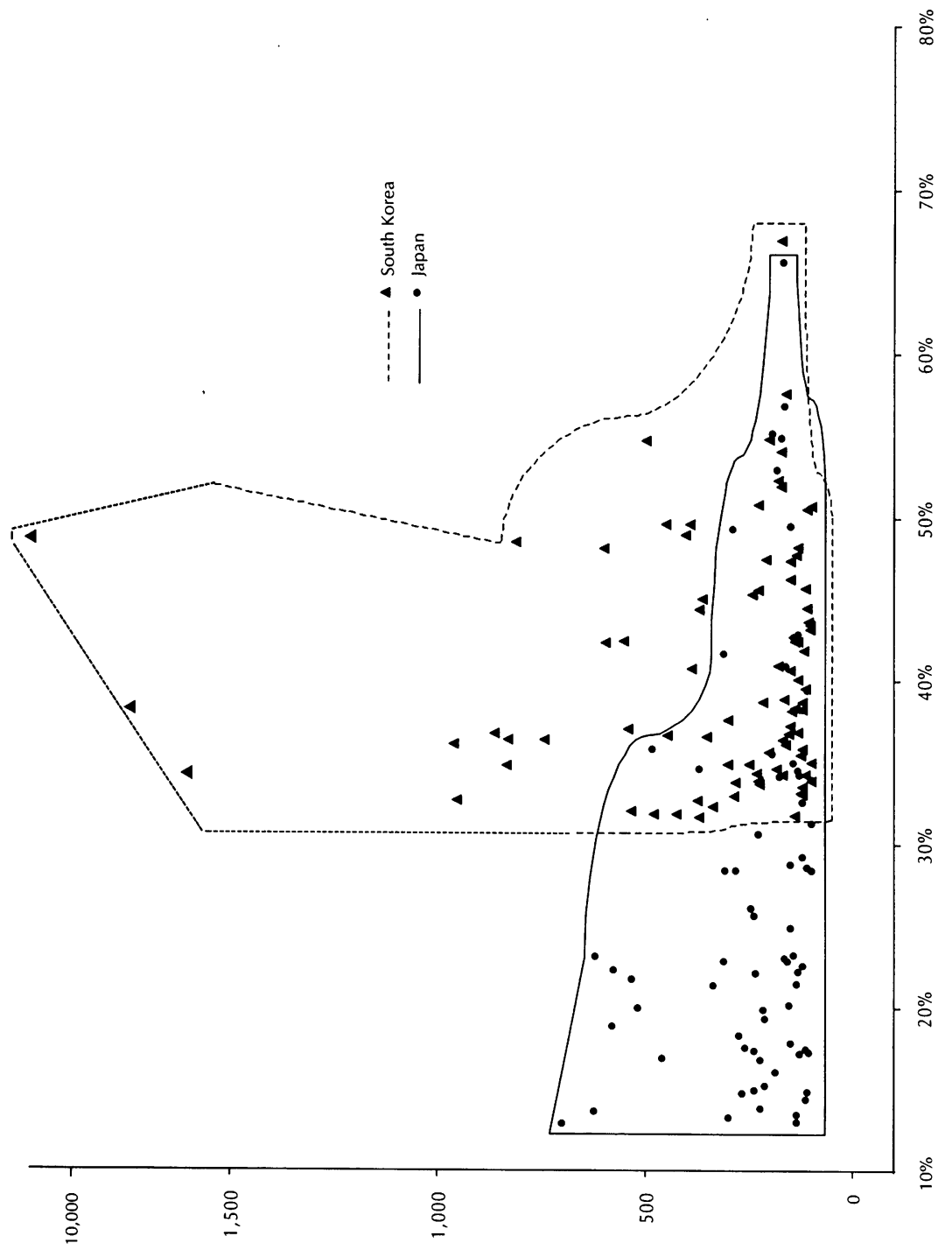


Figure 3-2. Distribution of Share Control Rates and Capital (2)

By capitalization

Japanese top $20 \%$ (71 enterprises)

South Korean top $20 \%$ (89 enterprises)

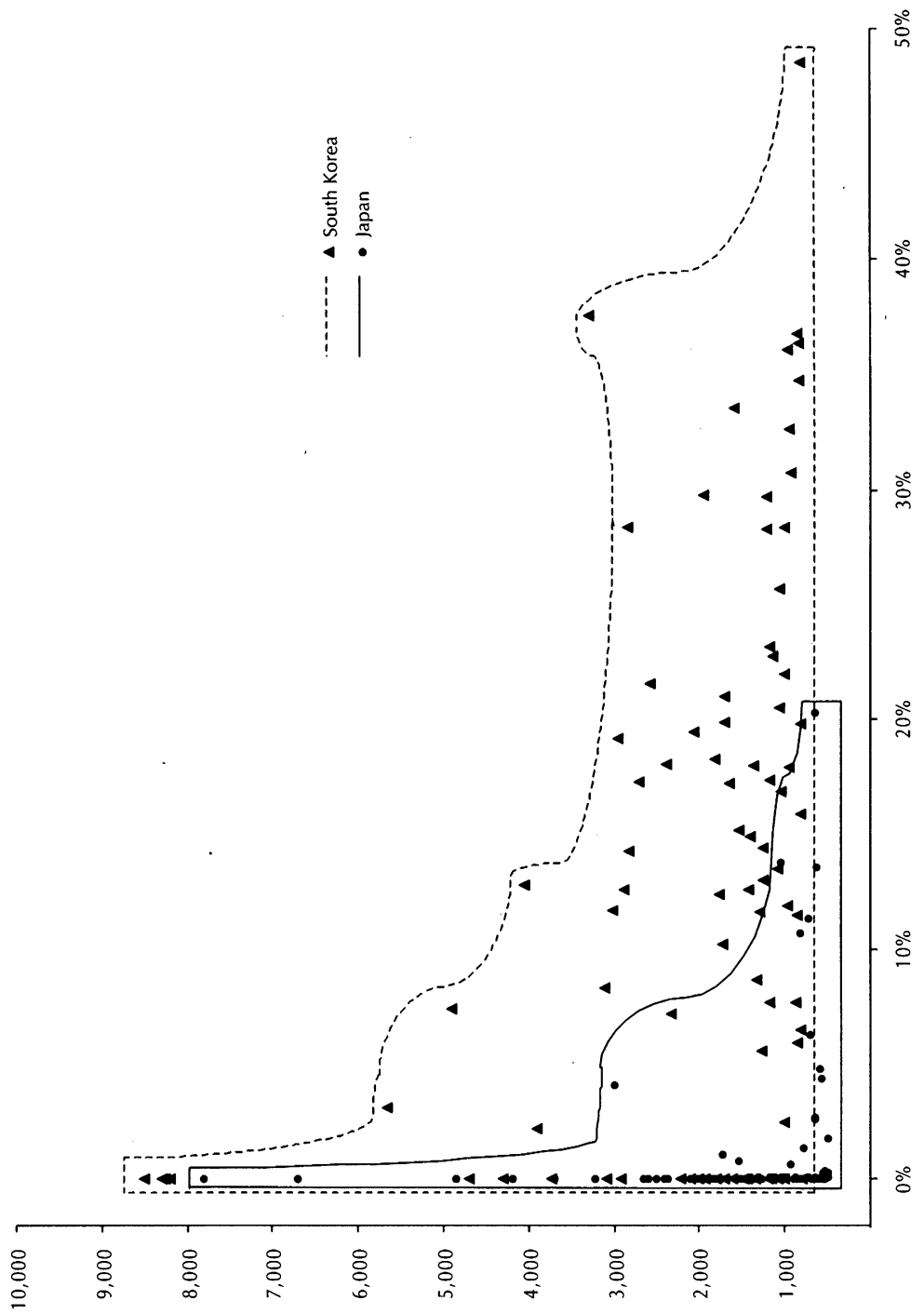


let me mention that the scale of capital of Japan's 71st enterprise is 48.4 billion yen, while that of South Korea's 89 th is 73.7 billion won.

As a result of this analysis it can be seen that the share control rate is high in South Korea even in enterprises whose scale of capital is large, and this shows that a specific individual (usually a founder) or the founder's family occupies the highest management position and also has retained controlling power over most of the shares. The obverse of this is that there is extremely little scope for the rise of salaried managers in the present situation in South Korea. This might be connected with the fact that the average year of establishment of the enterprises in the South Korean sample is 1965 (the same average held for both the 317 enterprises whose share control rate was $10 \%$ or higher, and the 127 enterprises whose share control rate was under $10 \%$ ), so that only 30 years have elapsed since their founding-in other words, they are still in the founder's generation.

The existence of salaried managers is acknowledged in financial institutions and a portion of the government enterprises, as well as in a small portion of enterprises in the manufacturing industry, but most of these enterprises are what Morikawa categorized as "Wandervogel types" (Morikawa 1996, 8). These are a far cry from the "salaried managers" in the original sense meant by Morikawa: managers who have strong networks with all levels of management and make good use of them. Samsung, a representative South Korean enterprise group, first began open employment in the late 1950s; some of those who joined the company through this avenue have become "salaried managers" who have gone all the way to becoming chairman of a subsidiary enterprise. There are some other enterprise groups, too, that, like Samsung, have definitely established internal promotion routes and some salaried managers. There is still a lingering doubt, however, about the extent of authority sharing that takes place between the present group chairmen (who are members of the founders' families) and these salaried managers.

In Japan, on the contrary, large numbers of enterprises have already moved on to becoming "manager enterprises." And it can be clearly seen that there is a tendency for a higher percentage of them to be "manager enterprises" as the scale becomes greater. As 
I mentioned earlier, the average year of establishment of the "nonmanager enterprises" is 1958 while the average year of establishment of the "manager enterprises" is 1951, so this difference of seven years may have something to do with such a move. Still, it remains doubtful whether or not the eleven year difference between the average year of establishment of Japan's enterprises (1954) and that of South Korea's enterprises (1965) is sufficient to explain the great difference we have seen in Japanese and South Korean enterprises.

\section{THE PROBLEMS THAT REMAIN}

We have to admit that we cannot wholly explain the difference between Japan and South Korea in the frequency of appearance of "manager enterprises" by a difference of about ten years in the years of their establishment. I have acknowledged (Hattori 1994a, b) that the share control power and management control power of South Korean families is on the wane, but at the same time I have pointed out that a considerable part of the waning of control over shares is complemented by the mutual holding of shares among affiliated enterprises; as the scale of capitalization of an enterprise rapidly increased, owner families tried in some way or other to retain controlling power over the shares. This mutual holding of shares is an effort to survive as a "family enterprise"; to put it from the opposite angle, it is resistance from the ownership side against the move to a "manager enterprise," and one has to consider the existence of some kind of social pressure making such resistance seem a natural thing to do. ${ }^{4}$

That raises a different question. Why is it that in Japan, even though there are many families that do not have as high a share ownership percentage as they do in South Korea, these families can choose successors from among family relatives? There is no space to go into a discussion of this question here, but I believe there are at least two reasons for this. The first is that, the greater the founder is, the greater is the impact of his death upon the

\footnotetext{
${ }^{4}$ What I mean by "social pressure" is something close to Yasuoka's "social climate."
} 
organization, so that there exists a logic in the organization that would seek the centripetal force of the organization in the family that (possibly) has inherited the founder's charismatic appeal and abilities. Or else the founder trains his family within the organization to be his successor while he still has enormous influence, and tries to have the family's abilities recognized by those around them. It is for this reason that even today one often hears in Japanese enterprises the premodern expression "taisei hōkan" [Restoration of the Imperial Rule].

The second reason that can be given are the structural features of share ownership. In the share ownership structure of not a few enterprises the ownership percentages of financial organizations in particular compete with each other. In a certain enterprise, for example, even though the family members together own only $5.1 \%$ of the shares, they have secured the posts of chairman and president. These two men are numbered among the ten largest shareholders, with all the other eight being financial organizations; because two of these organizations hold almost exactly the same percentage of shares, one of them is unable to send a representative to this enterprise. In other words, in this enterprise the founder's family is riding on a balance of share ownership by competing financial organizations (Hattori 1996). Since the reason financial organizations become shareholders in an ordinary enterprise is more the strong expectation that it will ensure them a client to finance rather than the idea that they will be able to control that enterprise, as long as the enterprise is not on the verge of any serious crisis the founder's family is assured of having a free rein in management.

It is believed that the reason why in Japan founder families can retain their strong influence in the area of management even after they have become minority shareholders is that the above power relationships in the area of ownership and a social "mood" have an effect on the situation. Still, even supposing the existence of such a tendency, there is a major thrust in Japan for a "founder enterprise" or a "family enterprise" to change into a "manager enterprise as time passes and the scale of the enterprise becomes larger, which seems to accord with what Morikawa said. 
In South Korea, however, that thrust is not as clear as it is in Japan. As I indicated in an article referred to above (Hattori $1994 \mathrm{~b})$, this is because a move from a "founder enterprise" to a "family enterprise" is considered perfectly natural, and there exists an extremely strong desire to try to go on maintaining it as a "family enterprise." Almost none of the large enterprise groups on the order of the top thirty enterprise groups, except for those that are bank-related or government-enterprise-related, have a salaried manager as the successor of the group chairman. Some of the groups have moved into the third generation, but the same thing is true of them, too. One cannot avoid sensing the existence of a strong desire to keep on owning and controlling the enterprise. Even the fact that many of the enterprises are divided at the time of a generational change can be thought of as another expression of the same strong desire.

\section{IN CONCLUSION}

It has been demonstrated that the theory of management form transition proposed by Hidemasa Morikawa is a valid one, at least in Japan. It is true that the transition interval between forms was speeded up by the unusual condition of a zaibatsu dissolution, but even if that condition had not existed the probability that enterprises would have progressed in the direction indicated by Morikawa is high. This is, it is believed, because there existed in Japan the "institution" of the family and the tradition of the "banto seido" [head clerk institution], by which the most suitable person to maintain that family is chosen. In his work Morikawa (1996) seems to be using the arguments of Chandler and taking the similarity between phenomena in Japan and in the United States as the grounds for attributing universality to his theory, but I have a suspicion that it is a similarity of patterns as effects, and not something that indicates an identity of the mechanism that produces the patterns. ${ }^{5}$

\footnotetext{
${ }^{5}$ We have argued before, in a study (in a slightly different area from that of the present study) in which we compared the economic developments of Korea and Taiwan, the need to distinguish patterns and mechanisms. That study dealt with two
} 
What is that mechanism? I do not know enough about the business management situation in the United States to be able to identify it clearly, but I would hazard a guess that it is shareholder sovereignty. This is nothing more than a tentative hypothesis, but I wonder if it isn't the strong longing for the continuation of the "family" that created the "bantō seido" in Japan, that carries on even into the present, and that created management by means of salaried managers, while in the United States it is the strong profit motive of shareholders that created management by salaried managers.

What about South Korea, then? In South Korea there is a strong desire for the continuation of the family blood line and the family's prosperity. There the enterprise is the history of the family and at the same time its property. It is psychologically very difficult to entrust a family's history and property to a salaried manager who is not related by blood, no matter how much he can be trusted. One is compelled to draw the conclusion in the present situation that the efforts by entrepreneurs to ensure the controlling power of the family when the scale of the enterprise is increasing rapidly, even if it involves increasing reciprocal ownership of related enterprises, are being driven by historical and cultural social pressures.

As I have shown in this study, in Japan "manager enterprises" are already overwhelmingly the mainstream, and two-thirds of the enterprises with a history of 40 or 50 years can be called "manager enterprises." In South Korea there are, it is true, some enterprises in the giant enterprise groups in which wide-ranging authority has been entrusted to internal-promotion-type salaried managers. Still, even these, it seems, cannot make a decision regarding important matters that ignores and goes against the will of the group chairman. This is no doubt because the family that is called the owner of the group enterprise has retained overwhelming influence over the shares, and because of the existence of historical and cultural tendencies behind this phenomenon. As a result, for "manager enterprises" to become the mainstream there would probably have to be a dramatic change in the South Korean economic environment.

countries that are called newly emerging industrial nations, and the performances of their economic development are similar, but we discovered that the mechanisms that brought about those performances were quite different. For more details see the introductory chapter of Hattori and Satō 1996. 


\section{REFERENCES}

Chandler, A. D.

1993 Sukèru ando sukōpu [Scale and scope]. Tr. Etsuo Abe et al. Yūhikaku.

Hattori, Tamio

1976 "Kankoku to Nihon no kazoku ni tsuite no ichishikaku" [One viewpoint on the family in South Korea and Japan], Ajia keizai 17-3.

1984 "Gendai Kankoku kigyō no shoyū to keiei" [Ownership and management of contemporary South Korean enterprises], Ajia keizai 25-5/6.

1988 Kankoku no keiei hatten [South Korea's business management development]. Tokyo: Bunshindō.

1994a "Kankoku 'chaebol' no shoyū to keiei: sairon" [Ownership and management of South Korean chaebol: A rethink] , Tökyō Keidai gakkai shi 188.

1994b "Kankoku 'chaebol' no shōrai-'chaebol' no seichō to suitai shiron" [The future of South Korea's chaebol: An essay on their growth and atrophy], in Kiro ni tatsu Kankoku kigyō keiei [South Korean enterprise management at the crossroads], ed. Takao Makito (Nagoya: Nagoya Daigaku Shuppankai).

1996 Paper presented at the Japan-South Korea Joint Conference of the Organization Society (April).

Hattori, Tamio and Yukihito Satō

1996 Kankoku, Taiwan no hatten mekanizumu [Development mechanisms in South Korea and Taiwan]. Ajia Keizai Kenkyūjo [Institute of Developing Economies].

Matsumoto, Kōji

1985 "Kankoku no keizai shakai to kigyō taisei" [South Korea's economic community and enterprise system], Keizai hyōron 34-6.

Mito, Tadasu

1991 Ie no ronri [Logic of the family]. Tokyo: Bunshindō.

Morikawa, Hidemasa

1996 Toppu manejimento no keieishi [The business history of top management]. Yūhikaku. 
Suehiro, Akira

1993 Paper presented at the 29th National Conference of the Business History Society.

Yasuoka, Shigeaki

1995 "Shoyū to keiei no kokusai hikaku shiron" [A tentative international comparison of ownership and management], Shakaikagaku [The Social Science] 55 (published by Dōshisha University's Institute for the Study of Humanities and Social Science). 